\section{Angio-oedema and urticaria associated with angiotensin converting enzyme inhibitors}

Many drugs have been reported to cause angio-oedema and urticaria, conditions that often coexist.' We reviewed reports to the Committee on Safety of Medicines of such reactions that occurred with the two angiotensin converting enzyme inhibitors captopril and enalapril.

\section{Methods and results}

All reports from the United Kingdom of suspected adverse reactions to captopril and enalapril received by the Committee on Safety of Medicines from the dates they were first sold (May 1981 and January 1985, respectively) up to January 1986 were examined.

Enalapril-Thirteen patients developed angio-oedema (table); one also developed urticaria. The reaction occurred after the first dose in six patients and within five days in the remainder. No formal rechallenge tests were described though the reaction occurred acutely after each of two doses taken by one patient. Angio-oedema resolved within one to two days after the drug was stopped in 12 patients; two patients were treated with steroids. Urticaria alone was reported in seven patients (four men) aged 46-80 (mean 59) after daily doses of 5-20 mg. Four patients had hypertension, and three with heart failure received concomitant diuretic treatment. The reaction occurred after the first dose in one patient, within four days in three, and within 10,14, and 16 days in the remainder. Drug withdrawal resulted in the resolution of signs in all patients within one to seven days.

Captopril-Six patients developed angio-oedema (table); three also developed urticaria. The reaction occurred two to 28 days after treatment started and resolved within one to four days after drug withdrawal in four patients. The outcome in the two other patients was unknown. Urticaria alone was reported in 17 patients (14 women) aged 53-78 (mean 64). Fifteen were being treated for hypertension and two for heart failure, with daily doses of $25-150 \mathrm{mg}$. The reaction occurred one hour after the first dose in one, after three days in two, and after 8-60 (mean 31 ) days in the remaining patients. The signs resolved within six days after drug withdrawal in 16 patients but persisted for two to four weeks after treatment was stopped in two others. A positive result of rechallenge was reported for two patients.

\section{Comment}

A causal association between angio-oedema or urticaria and enalapril and captopril is supported by the temporal relation of these reactions to the start of drug treatment, the rapid resolution of the conditions on withdrawal of the drug, and the absence of other likely causes. In a few cases there was a positive rechallenge.

Predisposing factors to either reaction could not be identified. There was no clear evidence for a dose-response relation, and the preponderance of men in the enalapril group and women in the captopril group may be fortuitous. Moreover, the under-reporting of adverse reactions to the Committee on Safety of Medicines, the absence of accurate data on patient exposure, and the differential patterns of use of the two drugs do not allow absolute or relative incidences of the reactions to be estimated.

In 14 of 19 patients who developed angio-oedema the reaction developed within five days; in 11 it occurred within $\mathbf{4 8}$ hours. Most instances of drug induced angio-oedema and urticaria are believed to be mediated by immunological mechanisms. ${ }^{1}$ Agents such as aspirin and certain non-steroidal antiinflammatory agents, however, may cause reactions by non-immune mechanisms. ${ }^{2}$ The onset of angio-oedema with angiotensin converting enzyme inhibitors seems to be too rapid in most cases reported for a specific immune response to have been stimulated. Unless captopril and enalapril cross react with other antigens to which the patients have previously been sensitised a direct immunological mechanism therefore seems unlikely. Evidence increasingly suggests that hereditary angio-oedema is mediated by kinins. ${ }^{3}$ As angiotensin converting enzyme is partially responsible for the inactivation of bradykinin and kallidin, ${ }^{4}$ and angiotensin converting enzyme inhibitors potentiate the effects of bradykinin in man, angio-oedema associated with such inhibitors may result from impaired kinin inactivation.

We are grateful to Professor Sir Abraham Goldberg and the Committee on Safety of Medicines for permission to report from the Adverse Drug Reactions Register.

Champion RH. Urticaria. In: Rook A, Wilkinson DS, Ebling FJG, eds. Textbook of dermatology. London: Blacknell, 1979:971-9.

2 Kaplan AP. Drug-induced skin disease. $f$ Allergy Clin Immunol 1984;73:573-97.

3 Schapira M, Silver LD, Scoll CF, et al. Pre-kallikrein activation and high molecular weight kininogen consumption in hereditary angioedema. $N$ Engl f Med 1983;308:1050-3.

Clinical data on patients who developed angio-oedema after taking enalapril or captopril

\begin{tabular}{|c|c|c|c|c|c|c|c|c|}
\hline $\begin{array}{l}\text { Case } \\
\text { No }\end{array}$ & $\begin{array}{c}\text { Age } \\
\text { (years) }\end{array}$ & Sex & $\begin{array}{l}\text { Daily } \\
\text { dose } \\
\text { (mg) }\end{array}$ & $\begin{array}{l}\text { Indication for } \\
\text { treatment }\end{array}$ & Medical history & $\begin{array}{l}\text { Other drugs } \\
\text { (daily dose) }\end{array}$ & Reported reaction & $\begin{array}{c}\text { Onset of } \\
\text { adverse } \\
\text { drug reaction }\end{array}$ \\
\hline \multicolumn{9}{|c|}{ Enalapril } \\
\hline 1 & 62 & $\mathbf{M}$ & 10 & Hypertension & None given & None & $\begin{array}{l}\text { Swelling of face, macular-papular rash on } \\
\text { face and arms }\end{array}$ & Five days \\
\hline $\begin{array}{l}2 \\
3\end{array}$ & $\begin{array}{l}59 \\
49\end{array}$ & $\begin{array}{l}\mathbf{M} \\
\mathbf{M}\end{array}$ & $\begin{array}{l}20 \\
10\end{array}$ & $\begin{array}{l}\text { Hypertension } \\
\text { Hypertension }\end{array}$ & $\begin{array}{l}\text { None given } \\
\text { None given }\end{array}$ & $\begin{array}{l}\text { None } \\
\text { None }\end{array}$ & $\begin{array}{l}\text { Acute facial oedema and urticaria } \\
\text { Mild angio-oedema and dyspnoea }\end{array}$ & $\begin{array}{l}\text { Four days } \\
\text { Two days }\end{array}$ \\
\hline 4 & 64 & $M$ & 10 & Hypertension & None given & None & Angioneurotic oedema & $<24$ Hours \\
\hline 5 & 62 & $\mathbf{M}$ & 10 & $\begin{array}{l}\text { Hypertension and congestive } \\
\text { cardiac failure }\end{array}$ & $\begin{array}{l}\text { Cardiomyopathy } \\
\text { (alcoholic?) }\end{array}$ & Neo-NaClex-K (one tablet) & $\begin{array}{l}\text { Swelling of face and abdomen. Gross penile } \\
\text { swelling of preglans area }\end{array}$ & After three doses \\
\hline 6 & 71 & $\mathbf{F}$ & 10 & Hypertension & None given & None & $\begin{array}{l}\text { Swollen tongue and feeling of suffocation } \\
\text { (two episodes) }\end{array}$ & Two days \\
\hline 7 & 74 & $\mathbf{M}$ & 10 & Hypertension & $\begin{array}{l}\text { Carcinoma of } \\
\text { prostate }\end{array}$ & $\begin{array}{l}\text { Stilboestrol ( } 3 \mathrm{mg}) \text {, verapamil } \\
\text { (320 mg) }\end{array}$ & $\begin{array}{l}\text { Face, tongue, and lips swollen on waking } \\
\text { (dose taken at bedtime) }\end{array}$ & $\begin{array}{l}<12 \text { Hours after } \\
\text { first dose }\end{array}$ \\
\hline 8 & 61 & $\mathbf{F}$ & 5 & Hypertension & None given & Bendrofluazide (5 mg) & Angioneurotic oedema & $\begin{array}{l}\approx \text { Six hours after } \\
\text { first dose }\end{array}$ \\
\hline 9 & 74 & $\mathbf{M}$ & 20 & Hypertension & None given & $\begin{array}{l}\text { Aspirin (one tablet alternate } \\
\text { days), Adalat Retard (two } \\
\text { tablets) }\end{array}$ & $\begin{array}{l}\text { Badly swollen face and eyelids. Reddening } \\
\text { of bald scalp }\end{array}$ & \\
\hline 10 & 50 & $\mathbf{M}$ & 5 & Hypertension & $\begin{array}{l}\text { End stage renal } \\
\text { failure }\end{array}$ & $\begin{array}{l}\text { Nifedipine }(60 \mathrm{mg}) \text {, atenolol } \\
\quad(100 \mathrm{mg}) \text {, calcium carbonate }\end{array}$ & Angioneurotic oedema & After three doses \\
\hline $11^{\star}$ & 46 & $\mathbf{M}$ & 10 & Hypertension & None given & None & Severe angio-oedema of face & $<24$ Hours \\
\hline $12^{\star}$ & 60 & $\mathbf{M}$ & 10 & Hypertension & None given & Moduretic (one tablet) & $\begin{array}{l}\text { Swelling of lips and tongue by evening after } \\
\text { morning dose. Worsening of swelling and } \\
\text { pruritus and difficulty breathing by next } \\
\text { morning }\end{array}$ & After first dose \\
\hline $13^{\star}$ & 58 & $\mathbf{F}$ & 10 & Hypertension & Arthritis & Fenoprofen (900 mg) & $\begin{array}{l}\text { Swollen tongue and lips with itching. } \\
\text { Difficulty breathing }\end{array}$ & $\begin{array}{l}16 \text { Hours after } \\
\text { first dose }\end{array}$ \\
\hline \multicolumn{9}{|c|}{ Captopril } \\
\hline 1 & 70 & F & 50 & Hypertension & None given & None & $\begin{array}{l}\text { Severe angioneurotic oedema of face. } \\
\text { Urticaria }\end{array}$ & 10 Days \\
\hline $\begin{array}{l}2 \\
3\end{array}$ & $\begin{array}{l}52 \\
45\end{array}$ & $\begin{array}{l}\mathbf{M} \\
\mathbf{F}\end{array}$ & $\begin{array}{l}50 \\
75\end{array}$ & $\begin{array}{l}\text { Hypertension } \\
\text { Congestive cardiac failure }\end{array}$ & $\begin{array}{l}\text { None given } \\
\text { None given }\end{array}$ & $\begin{array}{l}\text { Diazide (one tablet) } \\
\text { Frusemide ( } 40 \mathrm{mg} \text { ) }\end{array}$ & $\begin{array}{l}\text { Angio-oedema of lip } \\
\text { Angio-oedema, skin rash, and malaise }\end{array}$ & $\begin{array}{l}\text { Two days } \\
24 \text { Days }\end{array}$ \\
\hline 4 & 53 & $\mathbf{F}$ & 75 & Hypertension & None given & $\begin{array}{l}\text { Diazepam, oxyphenbutazone } \\
(300 \mathrm{mg})\end{array}$ & Angio-oedema and urticaria & 28 Days \\
\hline 5 & 62 & $\mathbf{M}$ & $37 \cdot 5$ & Congestive cardiac failure & None given & $\begin{array}{l}\text { Triptafen-M (three tablets), } \\
\text { dipyridamole }(300 \mathrm{mg}) \\
\text { frusemide }(40 \mathrm{mg})\end{array}$ & Angio-oedema & Five days \\
\hline 6 & 46 & $\mathbf{F}$ & 75 & Severe hypertension & None given & Frusemide & Facial oedema and severe urticarial rash & 13 Days \\
\hline
\end{tabular}


4 Yang HYT, Erdos EG, Levin Y. A dipeptidyl carboxypeptidase that converts angiotensin I and inactivates bradykinin. Biochim Biophys Acta 1971;214:374-6.

5 Kiowski W, van Brummelin P, Hulthen L, Amman FW, Bukler FR. Antihypertensive and renal effects of captopril in relation to renin activity and bradykinin-induced vasodilation. Clin Pharmacol Ther 1982;31:677-84.

(Accepted 19 September 1986)

Medicines Division, Market Towers, Department of Health and Social Security, London SW8 $5 \mathrm{NQ}$

SUSAN M WOOD, BSC, MD, senior medical officer

RONALD D MANN, MD, MRCP, principal medical officer

Wolfson Unit of Clinical Pharmacology, The University, Newcastle upon Tyne NE1 7RU

MICHAEL D RAWLINS, MD, FRCP, professor

Correspondence to: Dr Wood.

\section{Dihydroxypropoxymethyl guanine in the treatment of AIDS related retinitis due to cytomegalovirus}

Retinal changes in patients with the acquired immune deficiency syndrome (AIDS) have frequently been described recently. The changes include cotton wool spots, superficial and deep retinal haemorrhages, perivasculitis, and a type of retinitis presumed to be caused by cytomegalovirus..$^{1-3}$

In our experience five out of seven eyes have progressed unremittingly to complete blindness, and until recently no effective treatment had been found for this disease. The nucleoside 9-(1, 3 dihydroxy 2-propoxymethyl) guanine is being investigated as a possible treatment. Our cases confirm the findings of Palestine $e t a l^{4}$ that this drug is effective in treating retinitis caused by cytomegalovirus but that recurrence is likely after a single course of the drug.

\section{Case reports}

Case 1-A 54 year old homosexual man with AIDS and cytomegalovirus myelopathy complained of left sided temporal field loss. His reading vision was N5 in both eyes, and a patch of nasal retinitis was seen. Sixteen days later he had no perception of light in the left eye, and the entire retina was inflamed. The right eye remained normal. He was readmitted two weeks later after noticing visual field loss in the right eye. He received treatment with dihydroxypropoxymethyl guanine $350 \mathrm{mg}$ twice daily for two weeks, and during this time vision in the right eye remained $6 / 9$ and N6. One week after the course of treatment the retinitis became active, and within two weeks the vision was lost and he had no perception of light in either eye. He died three weeks later.

Case 2-A 31 year old homosexual man with AIDS related complex presented with bilateral follicular conjunctivitis. He had 6/9 vision in both eyes. Fundoscopy showed a large area of peripheral retinal necrosis with a surrounding fluffy white border of retinitis in the upper temporal retina of the left eye. A presumptive diagnosis of retinitis due to cytomegalovirus was made. Two weeks later he still had 6/9 vision in both eyes, but he had an increased peripheral field defect and increased retinitis. He was admitted to hospital and received a two week course of dihydroxypropoxymethyl guanine $350 \mathrm{mg}$ twice daily. During this period the area of retinitis remained static, but three weeks after he was discharged from hospital the vision in the left eye had deteriorated to registering only hand movements and the area of retinitis in the left eye had extended to the posterior pole (figure). There were disc haemorrhages, and the macula was oedematous. At this time a small patch of retinitis was noticed in the right eye. He received a further two week course of dihydroxypropoxymethyl guanine and then treatment with a maintenance dose five days a week. The retinitis in both eyes steadily improved (figure), and at the time of writing the visual acuity was $6 / 6$ in the right eye and had improved in the left from registering only hand movements to $6 / 12$.

\section{Comment}

Cytomegalovirus is a deoxyribonucleic acid (DNA) virus of the herpes group, which causes a distinctive "owl's eye" cytopathogenic effect. It has been shown to cause destructive retinitis in immunosuppressed patients, most frequently patients with renal allografts. The immune response to cytomegalovirus is directed against the immediate early phase viral protein products and is mediated by $\mathrm{T}$ cells and natural killer cells. ${ }^{5}$ The nucleoside dihydroxypropoxymethyl guanine acts by inhibiting DNA polymerase in a way similar to acyclovir.

In patients with renal allografts retinitis responds to a reduction in immunosuppressant drugs. In our patients we have seen a good biological effect of the drug dihydroxypropoxymethyl guanine on retinitis thought to be caused by cytomegalovirus. In both cases withdrawal of the drug led to a rapid recurrence of the disease. Dihydroxypropoxymethyl guanine seems to
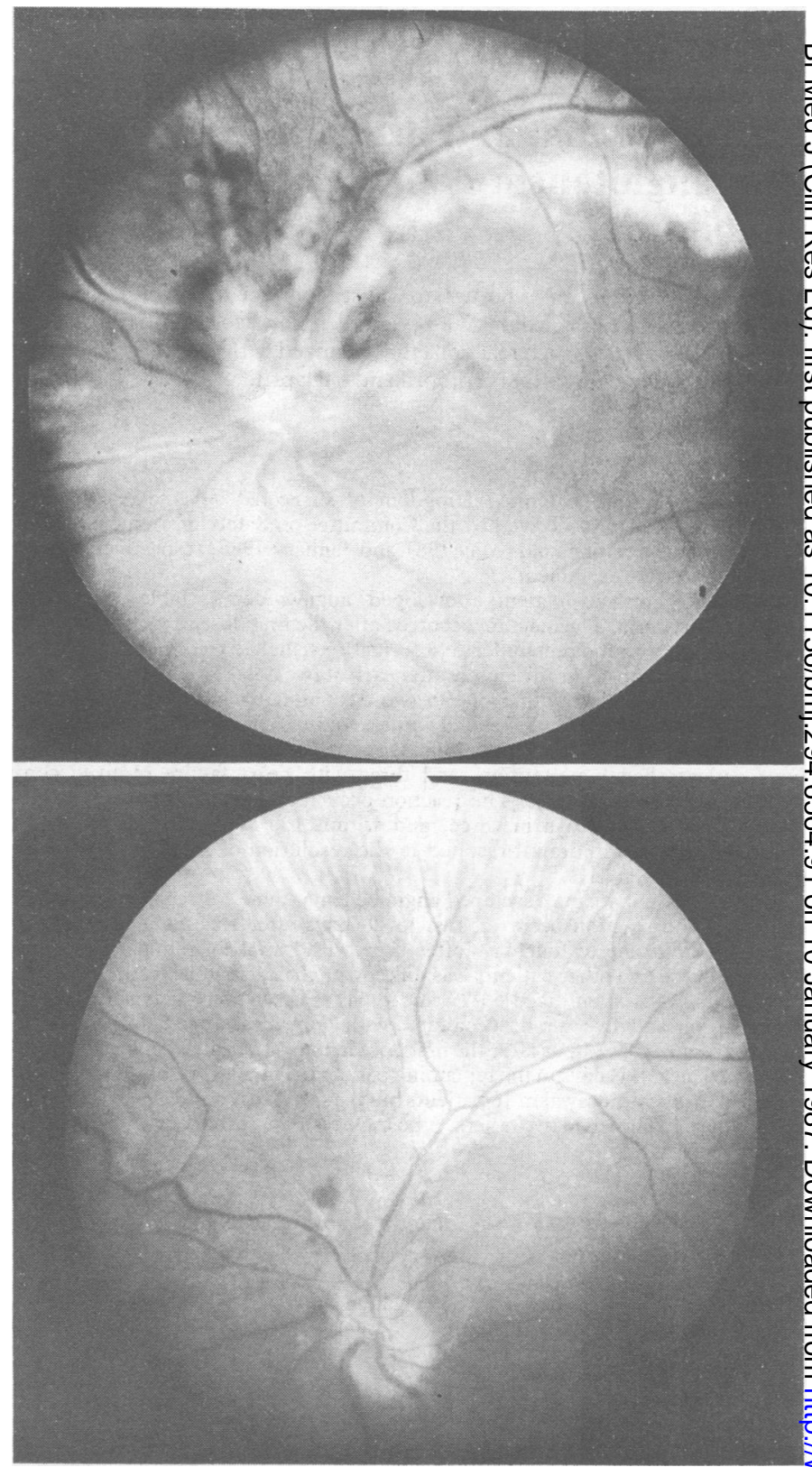

Case 2: active retinitis in left eye (above), and left eye after treatment with dihydroxypropoxymethyl guanine (below).

prevent deterioration of AIDS related retinitis but is effective only if given indefinitely and does not represent a cure. The myelotoxic effect of the drug given at a maintenance dose of $5 \mathrm{mg} / \mathrm{kg}$ daily is the main limiting factor of its long term efficacy as retinitis usually recurs when the drug is withdrawn.

We thank Syntex Corporation for supplying the dihydroxypropoxymethylo guanine; Dr D J Jeffries, Department of Virology, St Mary's Hospital, D Paddington, for help and encouragement; and Dr B Gazzard and Dr A Lawrence, St Stephen's Hospital, Chelsea, for permission to report these cases.

1 Khadem M, Kalish SB, Goldsmith J, et al. Ophthalmologic findings in AIDS. Arch Ophthalmok 1984;102:201.

Kestelyn P, Van de Perre $P$, Rouvroy D, etal. A prospective study of the ophthalmologic findings in AIDS in Africa. Am J Ophehalmol 1985;100:230-8.

Friedman AH, Orellana J, Freeman WR, et al. Cytomegalovirus retinitis: a manifestation of AIDS Br f Ophthalmol 1983;67:372-80.

4 Palestine AG, Stevens G Jr, Lane HC, et al. Treatment of CMV retinitis with dihydroxy propoxymethyl guanine. Am $\mathcal{f}$ Ophthalmol 1986;101:95-101.

5 Sissons JGP. The immunology of CMV infection. I R Coll Physicians Lond 1986;20:40-4.

(Accepted 30 October 1986)

St Stephen's Hospital, London SW10 9TH

M L HARRIS, MB, BS, ophthalmic registrar

M B R MATHALONE, FRCS, DO, consultant ophthalmologist

Correspondence to: Dr Harris. 